Iesaistītās organizācijas LLP nosacījımu izstrādē:

DEPA - Dānijas Vides aizsardzības aǵentūra;

DAAC - Dānijas Lauksaimniecības konsultāciju dienests;

JTI - Zviedrijas Lauksaimniecības mehanizācijas institūts;

ZM - Latvijas Zemkopíbas ministrija;

VARAM - Latvijas Vides aizsardzības un regionālās attīstības ministrija;

LVAF - Latvijas vides aizsardzỉbas fonds;

LLU - Latvijas Lauksaimniecības universitāte;

LZF - Latvijas Zemnieku federācija;

LLKC - Latvijas Lauksaimniecības konsultāciju centrs.

\title{
PROBLEMS WITH RECLAMATION OF ACID LAKES IN THE AREA OF MUŻAKOW LAKES
}

\author{
TADEUSZ CHRZAN \\ Prof., Dr. hab. \\ Technical University of Zielona Góra \\ str. Podgorna $65-246$, Poland \\ Phone: (068) 3254831, Fax: 48683245597
}

\begin{abstract}
In the paper is described actual state of environment after brown-coal exploitation with open-pit and deep-boring methods. The results of recultivationinvestigations are shown, which shown the problems of the strong acid lakesrecultivation. In the paper are also shown the geological and hydrogeological characteristics of the coal deposit area.
\end{abstract}

\section{Introduction}

In the Mużakow-Curve area the open-pit and deep-boring brown coal mining is leaded from the 100 years. As the result of this exploitation is occurred landscape's change - instead the pine-forests we have not covered with plants dump areas, excavations and acid lakes. After the mining activities the anthropogenic Lakeland origins with 100 lakes and 1000 ha of non-recultivated area.

\section{Geological characteristic of the Muzakow-Curve}

\subsection{Geographical localization}

The described areas are located in the neighborhood of polish-germane border in the middle of the Odra-river length. The Mużakow-Curve is a morphological upland in the form of semicircle open to the north. The south-polish glacier, running with the Lausitzian-Nysa ice-marginal valley formed it. The eminencies of the Curve are the end moraine, piled up and elevated to the $153 \mathrm{~m}$ a.s.1. Thrusting glacier caused the folding of the Tertiary sediments. As the result of this process the brown-coal deposits located deep under the ground level were putting up, what is good from the exploitation point of view. Actually the Mużakow-Curve is divided in the middle of length with Lausitzian- 
Nysa river valley. The first part of described area is located in Poland, the second one (at the other side of the river) in Germany. The lignite beds in the polish part of the Mużakow-Curve are forming in the Leknica-city locality the "Babina"-deposit. The beds are folded and under exploitation were the top-parts of the deposit's folds on the area a dozen or so $\mathrm{km}$ length. The folds are till $140 \mathrm{~m}$ deep.

\subsection{Geological structure [1]}

The oldest sediments are clays, mudstones and limestones of upper Cretaceous period. On this layer are lying Tertiary sediments depths about $115 \mathrm{~m}$. In these sediments are occurred 4 lignite beds:

1) on the $50 \mathrm{~m}$ depth - bed "Lausitzian Henryk", with seam thickness about 7,0m,

2) on the $65 \mathrm{~m}$ depth - bed "Lausitzian II", with seam thickness about $13,5 \mathrm{~m}$,

3 ) on the $95 \mathrm{~m}$ depth - bed "Ścinawski - Lausitzian III", with seam thickness about $6,0 \mathrm{~m}$,

4) on the $110 \mathrm{~m}$ depth - bed "Głogów - Lausitzian IV", with seam thickness about $4,0 \mathrm{~m}$.

These beds, especially not deeply lying (and from this case under exploitation), are surrounded by the sand-mudstone sediments with a large amount of micas.

Until the $20 \mathrm{~m}$ deep from the ground surface occur also alternately sandbanks and gravelbanks with clays-interbeddings.

Between 20 and $50 \mathrm{~m}$ occur a thick clay and sludge-layer, which are exploited for the refractories production.

From the geological structure results, that both: surface grounds and afterexploitation grounds (clays and sludges) are not suitable for recultivation process in the forest and grassland directions.

\subsection{Hydrogeological conditions}

The ground waters occur locally in the Quaternary sand-gravel formations over the clay-formations. The deepness of these waters enriched $15 \mathrm{~m}$. The Tertiary ground waters are building a few aquifers with depth till $20 \mathrm{~m}$. They are separated through clay, sludges and lignite layers. The water occurs in the sand layers, with parts diameters from coarse-grained sand to the silty sand. They are the waters under pressure about 550 $\mathrm{kPa}(55 \mathrm{~m}$ of the water column) propagated to the long distances.

\subsection{Lignite exploitation}

The beginning of the lignite mining in the Mużakow-Curve locality is connected with Raszyn-mine opening in 1863. The little mines were conglomerated in the mineenergetic complexes, as Tschöpelner Mine Company with $12 \mathrm{MW}$ power rating and annual coal-output 330 thousand-Mg. The bigger open-pit mine was Tuplice Mine, working for the glass-works, with annual coal-output 42 thousand $\mathrm{Mg}$. In the year of 1898 was opened deep-boring mine "Wiktor" in the Trzebiel-village, working for the glass-work, with annual coal-output 110 thousand $\mathrm{Mg}$.

In the 1945 were started the mines: "Babiba" (near Eeknica-city) and "Henryk", next "Smogóry", "Słone", "Maria" and "Sieniawa". In the 1971 the total coal-output was 700 thousands $\mathrm{Mg}$. In the following years (till the 1976) the lignite-mines were progressively closed, left the region with many strongly transformed, non-recultivated areas. The amount of transformed areas is shown in table 1. 
The areas transformed by the mining activity [4]

\begin{tabular}{lll}
\hline Mine & Locality & Area in ha \\
\hline Tuplice, Wiktor & Tuplice, Trzebiel & 460 \\
\hline Smogóry & Smogóry & 40 \\
\hline Sieniawa & Sieniawa & 83 \\
\hline Maria, Emma, Matylda & Lasocin, Nieciecz, Królikowice & 60 \\
\hline Tschöpelner M.Comp. & Nowe Czaple, Eeknica, Bronowice & 432 \\
\hline \multicolumn{1}{c}{ Total area } & & 1190 \\
\hline
\end{tabular}

After deep-boring exploitation the breaking down of the chambers and headings weré ccurred.

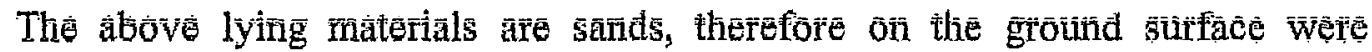
formed long and natrow sink-troughs, which next were filled with rain or ground waters. Open-pit excavations also were filled with rain and ground waters. This way between the Tuplice and Leknica-cities, on the length of $20 \mathrm{~km}$, was formed artificial anthropogenic Lakeland, with about 100 lakes 20 to 100 years old.

The 3 basins groups were specified:

- Tuplice-locality - 30 sink-basins and 11 ponds,

- Trzebiel and Kamienica-locality - 33 sink-basins,

- Chwaliszowice and Lęknica-locality - 40 sink-excavation- and excavation-basins.

The basins from the Tuplice locality are the oldest, with predomination of elongated shape and NE-SW direction, lying in the forest, with mild banks.

The steep and high banks characterize the second and third groups.

The most often the water basins have elongated shape length 95 to $896 \mathrm{~m}$, bright 20 to $468 \mathrm{~m}$ and asymmetric elongated profile. The one slope of the typical water basin is steep and the second one on the other side of basin is gently sloping. The basins are deep ( 3 to $24 \mathrm{~m}$ ) in compare with small water area $\left(2500\right.$ to $\left.202000 \mathrm{~m}^{2}\right)$.

The slopes of the basins, formed by the dumps-slopes are not so steep, strong eroded and naked and therefore less stable. The plants are farther from bank-line.

In the basins formed after lignite exploitation waters are weekly transparent, with rust-brown-color and very law $\mathrm{pH}$ value between 2,2 and 3,4 . The characteristic feature of these basins is presence of the ferrous sulfate $\left(\mathrm{FeSO}_{4}\right)$. This compound in the presence of oxygen formed in water the sulfuric acid. The alkalinity of the water is to small to neutralize formed sulfuric acid therefore the waters in such basins are strong acid.

\section{The actual state of the after-mining area}

The lignite exploitation in the Mużakow-Curve locality caused the changes in the hitherto existing landscape. On the big areas were damaged:

- pine-forests with the soil-layer,

- primarily plane terrain's surface.

Instead of this were formed dumps builds from cover material and the water basins.

The significant changes referred to the surface water run-off, and water aquifers layout (they were combined from primarily divided layers).

Instead of the pine-forest formation was originated the landscape typical for Lakeland, which consists from the depressions filled with water and non-covered with plants slopes of the dumps. The some lakes are temporarily drying-out, other have enough water for the local strings feeding. 
Cover material dumps are formed in predomination amount from silts and silty sands. From the mineralogical point of view the cover material consists of quartz, micas, lignite-dust, and muscovite with a small admixture of illite and caolinite. Also the ferrous sulfides (pyrite) are occurred in amount till 1\%. The dump-areas are till $25 \mathrm{~m}$ above primarily surface level high. They are cones-complexes with inclination till $45^{\circ}$. The top parts of these cones are not leveled and recultivated. Until the 1976 exist in Poland any law regulations imperative to the after-mining-areas recultivation.

The dump areas like these were heaped not far from excavations till the $40 \mathrm{~m}$ deep. After the lignite exploitation ending these excavations were filled with water, what gives the landscape of water-basin surrounded by the high dump-hills build from fine-grained and silt-materials.

The lakes created after the mining of lignite has ended have a very low $\mathrm{pH}$ level averaging from 2.8 to 3.5 (acid). And their potential, $\mathrm{Rh}$, is higher than $600 \mathrm{mV}$. The concentration of sulphates was 101 to $1488 \mathrm{SO}_{4} / \mathrm{dm}^{3}$ and concentration of ferrum was up to $182 \mathrm{mg}, \mathrm{Fe} / \mathrm{dm}^{3}$ (Table 2).

Table 2

Results of the examination of water in open pits of former lignite mines in the area of Mużakow lakes [4].

\begin{tabular}{lllllllll}
\hline $\begin{array}{l}\text { The place of water } \\
\text { sampling }\end{array}$ & $\mathrm{pH}$ & $\begin{array}{l}\mathrm{SO}_{4} \\
\mathrm{mg} / \mathrm{dm}^{3}\end{array}$ & $\begin{array}{l}\mathrm{Cl} \\
\mathrm{mg} / \mathrm{dm}^{3}\end{array}$ & $\begin{array}{l}\mathrm{Fe} \\
\mathrm{mg} / \mathrm{dm}^{3}\end{array}$ & $\begin{array}{l}\mathrm{Ca} \\
\mathrm{mg} / \mathrm{dm}^{3}\end{array}$ & $\begin{array}{l}\mathrm{Mg} \\
\mathrm{mg} / \mathrm{dm}^{3}\end{array}$ & $\begin{array}{l}\text { Mineral } \\
\text { acidity } \\
\mathrm{Mval} / \mathrm{dm}^{3}\end{array}$ & $\begin{array}{l}\mathrm{Fe}^{+2} \\
\mathrm{mg} / \mathrm{dm}^{3}\end{array}$ \\
\hline $\begin{array}{l}\text { A lake of the area } \\
\text { of 15.07 ha }\end{array}$ & 2.5 & 1488 & 28 & 33.3 & 153 & 138 & 5.5 & 3.0 \\
\hline $\begin{array}{l}\text { A lake of the area } \\
\text { of 3.52 ha }\end{array}$ & 2.2 & 632 & 17 & 29.7 & 74 & 77 & 2.7 & 2.8 \\
\hline $\begin{array}{l}\text { A lake of the area } \\
\text { of 6,86 ha }\end{array}$ & 3.4 & 321 & 49 & 7.2 & 63 & 41 & 0.6 & 1.2 \\
\hline $\begin{array}{l}\text { A lake of the area } \\
\text { of 2.80 ha }\end{array}$ & 3.0 & 557 & 40 & 24.2 & 95 & 69 & 1.4 & 2.8 \\
\hline $\begin{array}{l}\text { A lake of the area } \\
\text { of 3.34 ha }\end{array}$ & 2.9 & 693 & 19 & 27.3 & 93 & 79 & 2.6 & 3.0 \\
\hline
\end{tabular}

The chemical content of water is influenced by complex processes of pyrite decomposition which lead to the creation of sulphur acid and ferrum sulphate. $\mathrm{AFeS}_{2}$ pyrite located on the bottom of a lake can be subjected to:

a) oxidation according to the scheme:

- chemical oxidation: $2 \mathrm{FeS}_{2}+7 \mathrm{O}_{2}+\mathrm{H}_{2} \mathrm{O}=2 \mathrm{Fe}^{+2}+4 \mathrm{SO}_{4}^{-2}+4 \mathrm{H}^{+}$,

- biological oxidation by bacteria: $2 \mathrm{FeS}_{2}+7.5 \mathrm{O}_{2}+\mathrm{H}_{2} \mathrm{O}=2 \mathrm{Fe}^{+3}+4 \mathrm{SO}_{4}{ }^{-2}+2 \mathrm{H}^{+}$,

b) precipitation of trivalent ferrum compounds:

$\mathrm{Fe}^{+3}+3 \mathrm{H}_{2} \mathrm{O}=\mathrm{Fe}(\mathrm{OH})_{3}+3 \mathrm{H}^{+}$

The pyrite oxidation process can be generally as follows:

$2 \mathrm{FeS}_{2}+7 \mathrm{O}_{2}+\mathrm{H}_{2} \mathrm{O}=2 \mathrm{FeS}_{4}+2 \mathrm{H}_{2} \mathrm{SO}_{4}$

The pyrite oxidation by Thiobacillus ferrooxidans bacteria is 5 to 10 times faster than chemical oxidation.

4. Theoretical aspects of neutralisation of acid waters

The neutralisation of acid waters can be achieved using basic compounds or via biochemical reduction of sulphates to hydrogen sulphide using organic compounds. The 
neutralisation of acid waters can also be achieved via natural oxidation and reduction processes and exchange of chemical components between water, bottoms and atmosphere. The neutralisation of acid water can be achieved using chemical methods. by mixing it with strongly basic solutions or its filtration through a layer of basic materials (bed). To neutralise acid water one can use the following:

$\mathrm{NaOH}$ solution of 205 to $30 \%$ concentration,

$\mathrm{Ca}(\mathrm{OH})_{2}$, a milk of lime of $5 \%$ to $15 \%$ concentration,

$\mathrm{Na}_{2} \mathrm{CO}_{3}$ solution or $\mathrm{MgO}$ granulate.

The calculated [3] amount of $\mathrm{NaOH}$ in the waters of antropoghenic lakes is from 130 to $320 \mathrm{NaOH} / \mathrm{dm}^{3}$ and of lime is from 100 to $\mathrm{mg}, \mathrm{CaO} / \mathrm{dm}^{3}$. In the waters that lack oxygen the bacteria, Desulfovibrio desulfuricans reduce sulphates contained in waters with low $\mathrm{Rh}$ potential to sulphides, which in turn react with ferric ions causing the precipitation of $\mathrm{FeS}$ or $\mathrm{FeS}_{2}$.

As the result of laboratory studies [3] of waters from reservoirs No. 38 and 54 and municipal sewage and sewage from milk processing plants (mixed in proportion of 1:1) it was determined that such a mixture cause the growth of bacteria which produce sulphates, so after 24 days there was a significant reduction of sulphates and $\mathrm{Rh}$ potential and growth of $\mathrm{pH}$ to $5-6$ (Table 3).

\section{Conclusions}

Both theory and laboratory studies show that there is a possibility of changing acid waters from antrophogenic lakes to waters chemically neutral. It can be done using chemical or biological methods of sulphates reduction. It is proposed to use, as the source of carbon for bacteria which reduce sulphates, the following: wood dust, sawdust, sewage, paper industry wastes and wastes from milk processing plants which can be.obtained at almost no cost. The biochemical method is much cheaper than the chemical one.

On the laboratory scale the problem has been resolved.

Table 3

Examples of biochemical reduction of sulphates in the waters from the reservoir No. 38 [3]

\begin{tabular}{llllll}
\hline Time of measurements & pH reaction & $\begin{array}{l}\text { Redox } \\
\text { potential } \\
\mathrm{mV}\end{array}$ & $\begin{array}{l}\text { Sulphates } \\
\mathrm{mg} / \mathrm{dm}^{3}\end{array}$ & $\begin{array}{l}\text { Ferrum III } \\
\mathrm{mg} / \mathrm{dm}^{3}\end{array}$ & $\begin{array}{l}\text { Ferrum II } \\
\mathrm{mg} / \mathrm{dm}^{3}\end{array}$ \\
\hline $\begin{array}{l}\text { A. Sewage from millk } \\
\text { processing plants }\end{array}$ & & & & & \\
$\begin{array}{l}\text { After stirring } \\
\text { After 4 days }\end{array}$ & 3.1 & 633 & 367 & 35.8 & 4.1 \\
After 8 days & 3.3 & 631 & 342 & 20.9 & 4.2 \\
After 17 days & 3.4 & 628 & 342 & 16.3 & 4.2 \\
After 24 days & 3.4 & 621 & 318 & 12.2 & 4.6 \\
After 29 days & 4.2 & -51 & 256 & 6.2 & 5.1 \\
B. Municipal sewage & 5.0 & -182 & 112 & 1.2 & 5.3 \\
After stirring & 3.0 & 627 & 340.1 & 36.7 & 2.4 \\
After 4 days & 3.0 & 626 & 340.1 & 22.3 & 3.5 \\
After 8 days & 3.2 & 619 & 316.1 & 18.1 & 4.3 \\
After 17 days & 3.25 & 518 & 316.1 & 11.2 & 4.3 \\
After 24 days & 3.9 & -86 & 286.2 & 7.2 & 5.3 \\
After 29 days. & 5.2 & -170 & 156 & 1.8 & 5.7 \\
\hline
\end{tabular}




\title{
REFERENCES
}

Chrzan T. Badanie środowiska naturalnego na terenach pogórniczych Środkowego Nadodrza. Zielona Góra Polytechnic, 1998.

Jędrczak A., Solski A. Skład chemiczny wód zbiorników pojezierza antropogenicznego $w$ rejonie Tuplice - Eęknica. Zeszyty Naukowe No. 84, Higher School of Engineering, Zielona Góra, 1988.

Jędrczak A., Solski A. Teoretyczne podstawy możliwości odnowy wód kwaśnych. Zeszyty Naukowe No. 114, Zielona Góra Polytechnic, 1997.

Wróbel A. Zmieniajace się krajobrazy. Zeszyty Naukowe No. 114, Zielona Góra Polytechnic, 1997.

\section{TROKSNIS UN VIBRĀCIJA VIDĒ - VIDES KVALITATES KRITERTII}

\author{
JĀNIS DUNDURS \\ Ķìmijas zinātnu doktors \\ Rịgas Stradiña universitāte, Darba un vides veselības institūts, \\ Aroda un vides medicinas katedra, \\ Dzirciema ielā 16, Rīga, Latvia, LV - 1007 \\ T.: 409127 \\ MIERVALDIS LĀCIS \\ SIA Akustika, \\ Kurzemes prosp. 3, Rìga, Latvija, LV - 1067 \\ F.: 2417212
}

\begin{abstract}
Ievads
Vibrācija un troksnis ir vieni no visizplatītākajiem vides fizikālajiem piesārņotājiem, kas rada diskomfortu, īslaicīgus, pārejošus veselības traucējumus, kā arī var izraisīt vai veicināt dažāda veida saslimšanas, kuras atsevišķos gadijumos noved pie invaliditātes (vājdzirdība, kurlums, vibrācijas slimības IV stadija u.c.). Tiek pat uzskatīts, ka troksnis ir viena no vislielākajām mūsu gadsimta nelaimēm un viens no galvenajiem stresa izraisītäjiem.

Ar trokšña un vibrācijas problēmām ir jāsastopas gan sadzīvē, gan arī darba vidē. Transporta kustība pilsētās un kokapstrādes rūpniecỉba, diskotēkas un tekstilrūpniecība, lidostas un ǵimeniskas ķildas, dzērāju klaigāšana, skaļa mūzika daudzdzīvokḷu namos - tas viss ir paaugstināta trokšña un vibrāciju cēlonis. Ir zināms, ka apmēram $15 \%$ no visā pasaulē nodarbinātajiem ir pakḷauti trokšña kaitīgajai ietekmei. Latvijā no ik gadus pirmreizēji reǵistrētajām arodslimībām aptuveni $15 \mathrm{li} \mathrm{dz}$ $30 \%$ ir dzirdes orgāna saslimšanas un apmēram tikpat daudz tiek diagnosticētas kāa vibrācijas slimība. Patiesībā šo saslimšanu skaits ir lielāks, jo jānem vērā, ka mūsu valstĩ vēl nav sakārtots arodekspertīzes registra darbs.
\end{abstract}

